\title{
Effect of extreme rain and land covering change in Jatihandap on 20 March 2018 flash flood
}

\author{
Agung Wiyono Hadi Soeharno ${ }^{1, *}$, Mohammad Farid ${ }^{1}$, Dhiya Salma Abidah ${ }^{2}$, Tias Ravena Maitsa ${ }^{2}$, Setianingsih ${ }^{3}$, and \\ Nurul Majidah ${ }^{4}$ \\ ${ }^{1}$ Water Resources Engineering Research Group, Faculty of Civil and Environmental Engineering, Institut Teknologi Bandung, \\ Bandung, Indonesia \\ ${ }^{2}$ Study Program of Water Resources Management, Faculty of Civil and Environmental Engineering, Institut Teknologi Bandung, \\ Bandung, Indonesia \\ ${ }^{3}$ Study Program of Meteorology, Faculty of Earth Sciences and Technology, Institut Teknologi Bandung, Bandung, Indonesia \\ ${ }^{4}$ Study Program of Infrastructure Engineering and Management, Faculty of Civil and Environmental Engineering, Institut Teknologi \\ Bandung, Bandung, Indonesia
}

\begin{abstract}
Flash flood occurred on March 20, 2018, in Jatihandap, Bandung City, West Java due to the overflow of Cipamokolan River. This has caused considerable losses, especially for people living in the area. The flood occurred due to high rainfall intensity and inadequate land covering, especially in the upstream area (North Bandung Region) where the area is filled with housing, villas, and open land. Consequently, the water catchment area decreases. The objective of this study is to identify flood discharge that occurs due to high rainfall intensity and land covering. Flood discharge is calculated using a rational method. Based on BMKG data, rain intensity on March 20, 2018, is $45 \mathrm{~mm} /$ hour. The results of this study show that with this intensity, the Cipamokolan River flow brings water with sediment and debris waste. The discharge of the river is $207 \mathrm{~m} 3 / \mathrm{s}$. It equals to 2.2 times river basin discharge and causing water to overflow into the land around the river. The debris flow also damage the levees in Jatihandap then it caused flash floods.
\end{abstract}

\section{Introduction}

North Bandung Area (KBU) is one of strategic area in West Java. Its southern and western area is bordered by contour lines at 750 meters above sea level while at its northern and eastern area is borders by mountain ridge which connects Burangrang, Maigit, Gedongan, Sunda, Tangkuban Parahu and Manglayang Mount [1]. It is a protected and restricted water catchment area. Only about $20 \%$ of the total area that can be built under certain conditions and the remaining $80 \%$ of the total area is designated as conservation land since the Dutch colonial era. The area has been designated as a conservation area because this area has high water absorption potential. But now, development activities in the region are out of control. The green area that is the place for water catchment is decreasing due to the rapid construction of housing and villas. With the reduction of green land, the surrounding land will become easily eroded.

Cipamokolan River is one of the Upstream Citarum Rivers. Its upper is located in the North Bandung Region, so that land cover and erosion that occur in this area greatly influences runoff and sediment that enters the river. It also affects the amount of discharge flowing in the river.High rainfall fell on March 20, 2018, causing very high water runoff. Furthermore, KBU and its surroundings are a densely populated area. Consequently, it can cause high erosion on the land around KBU. So it can cause landslides and debris flow in the Cipamokolan River.

Debris flow is a flow that carries high concentrations of sediments and often carries large stones and tree trunks. Besides that, the high sedimentation and the accumulation of garbage in the river make the river's capacity decreases, eventually, the water overflows to the surrounding land. The high river flow and the amount of debris waste cause debris to accumulate at one river point that can keep the flow of water flowing from upstream. At one time the pile of garbage is not able to resist the flow again and will drift back with a larger flow discharge. This can damage water structures and river slope reinforcement in the surroundings. As a result, there is a flash flood like what happened in the residential area of Jatihandap and its surroundings which caused one of the embankments in the area to collapse and one house in the sub-district of Jatihandap was washed away.

Flash floods are associated with short, high-intensity rainfall rates, mainly of convective origin that occurs 
locally. Runoff rates often far exceed those of other flood types due to the rapid response of the catchments to intense rainfall, modulated by soil moisture and soil hydraulic properties [2]. Meteorological, Climatological, and Geophysical Agency (BMKG) has classified rainfall intensity in Indonesia into 4 categories (Table 1).

Table 1. Rainfall intensity classification

\begin{tabular}{|l|l|}
\hline Category & \multicolumn{1}{|c|}{ Rainfall intensity } \\
\hline Mild & $1-5 \mathrm{~mm} /$ hour; or $5-20 \mathrm{~mm} /$ days \\
\hline Moderate & $5-10 \mathrm{~mm} /$ hour; or $20-50 \mathrm{~mm} /$ days \\
\hline Heavy & $10-20 \mathrm{~mm} /$ hour; or $50-100 \mathrm{~mm} /$ days \\
\hline $\begin{array}{l}\text { Very } \\
\text { Heavy }\end{array}$ & $>20 \mathrm{~mm} /$ hour; or $>100 \mathrm{~mm} /$ days \\
\hline
\end{tabular}

Citarum Watershed consists of dozens of subwatersheds include the watershed located in KBU. Based on the results of the spatial analysis, the watersheds located in the KBU are Cikapundung, Cidurian, Citepus, Cimahi, Cilember, Cimeta, Cikeruh, Cisomang and Cihaur sub-watersheds. Each of these sub-watersheds varies in physical characteristics such as the area and geomorphology, conditions of land cover vegetation and built-up land, and the level of soil potential to absorb rainwater.

Based on the land cover data in 2014, sub-watersheds in KBU are in such poor condition, since the forests only have a few proportions in the upstream sub-watersheds. Such as in Cikapundung Sub-Watershed, its forest area is only 1,558 Ha or $10 \%$ of the Cikapundung Sub-watershed total area $(14,956 \mathrm{Ha})$. The Citepus Sub-watershed forest area is $133 \mathrm{Ha}$ or about $1.77 \%$ of its total area $(7,571 \mathrm{Ha})$. Then the Cidurian Sub-watershed forest area is only 253 Ha or $2.38 \%$ of the Cidurian Sub-watershed total area $(10,616 \mathrm{Ha})$.

Cicaheum is located in the Cidurian Sub-watershed. Based on the data above, its forest area is only $2.38 \%$ meanwhile the area of built land is $38.87 \%$. It shows that the proportion of the forests is very unbalanced. On the other hand, to sustain sub-watersheds' role as water catchment area and function to resist flash flood, the forests area in the upstream should be enough to keep the rainfall absorption circulation into the ground [3].

Through this paper, the author will discuss the influence of rainfall and land covering on flood discharge that occurred during the flash flood event in Jatihandap on March 20, 2018.

\section{Study area}

Geographically, Citarum Watershed is located in $6^{\circ} 43^{\prime} 21,8$ " $-7^{\circ} 19^{\prime} 38,1^{\prime \prime}$ LS and $107^{\circ} 32^{\prime} 2$ "-107053'51,6" BT. The overall Upstream Citarum Watershed area is $1,771 \mathrm{~km}^{2}$ where the Bandung Basin is mostly surrounded by quaternary volcanic mountains and surface runoff eventually flows into the Citarum River [4]. Upstream Citarum has 13 tributaries, there are Citepus river, Cibolerang river, Cipamokolan river, Cisangkuy river, Ciwidey river, Citarum upstream river, Cikeruh river, Citarik river, Cidurian river, Cibeureum river, Cicadas river, Cigede river, and Cimahi river (Figure 1).

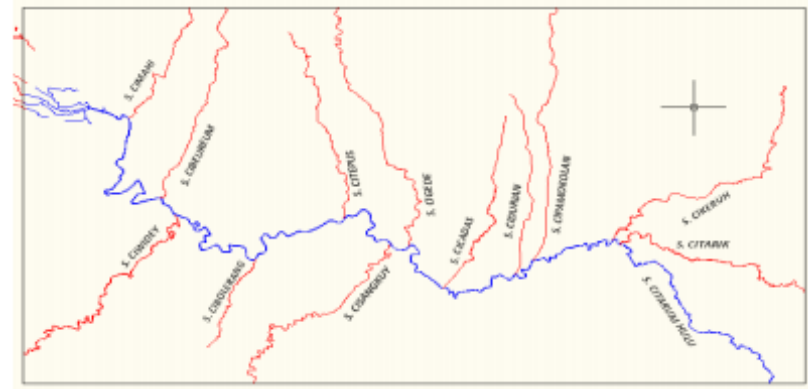

Fig. 1. Flash flood area at Jatihandap [4]

The main things in this study was Cipamokolan River. Its watershed area is $42.34 \mathrm{~km}^{2}$ with length $13.79 \mathrm{~km}$ and river slope is 0.012 [5].

On March 20, 2018, there was a flash flood caused by the breakdown of the levees on the Cipamokolan River which is a tributary of the Upstream Citarum River at Cicabe Street, Jatihandap Village, Mandalajati District, Bandung City, West Java. It was the first occurrences of flash flood in the region. The floods at that time brought high sediment concentrations and flooded residential areas and highways around them. The height of the inundation that occurred at that time reached $0.5-1 \mathrm{~m}$. The flood caused approximately 17 car and 1 house to be washed away by the flow. At least 617 houses in the area were flooded. Flooding also crashed shop houses in the area, causing the goods sold in the shop to be damaged and washed away. In addition, the inundaton was also reached Ahmad Yani Street, so there was a heavy traffic jam at that time.

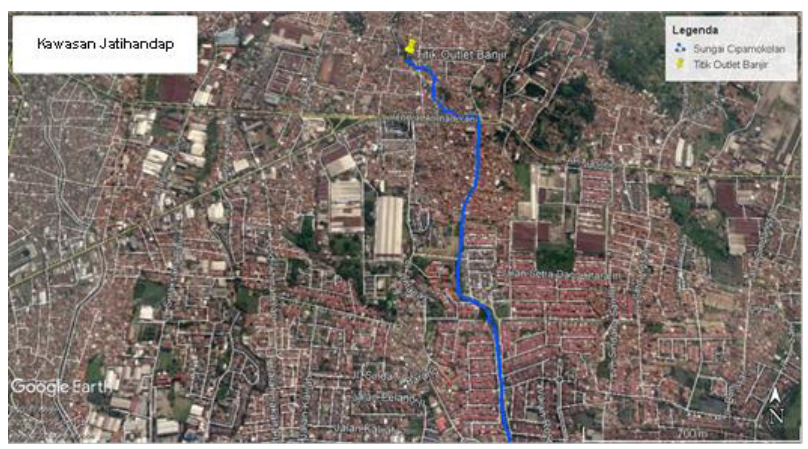

Fig. 1. Flash flood area at Jatihandap

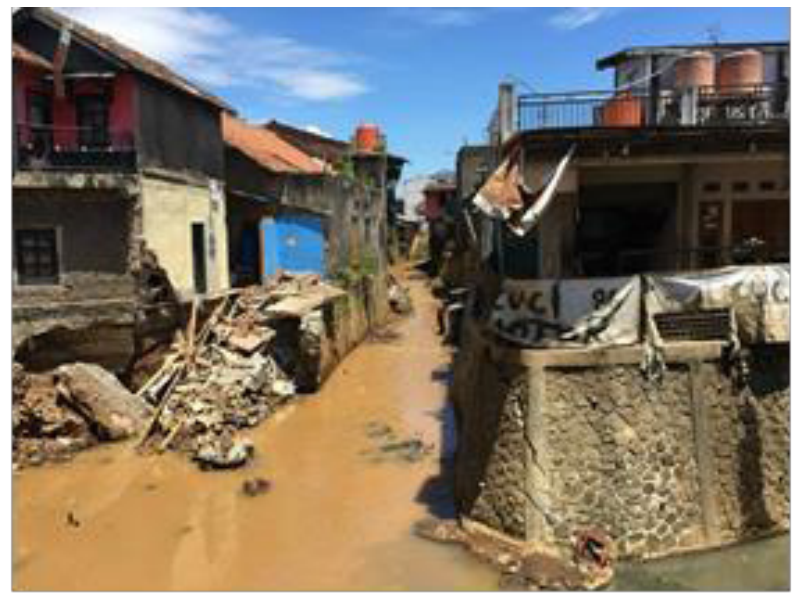

Fig. 2. Flash flood area at Jatihandap 


\section{Methodology Study}

\subsection{Data collection method}

To find out the flood discharge that occurred on that day, it requires rain data on that day and the area land covering data. Rain data is obtained from the BMKG statement. While for land covering in the area is done by looking at the images on Google Earth and conducting a survey directly to the field.

\subsection{Hydrological analysis method}

In this study, flood discharge was calculated using the rational method. The rational method can be used to calculate the peak flow of a river or channel with a limited drainage area. The rational method general formula is [6]:

$$
Q=C \times I \times A
$$

$\mathrm{Q}=$ Peak discharge runoff surface $\left(\mathrm{m}^{3} / \mathrm{s}\right)$

$\mathrm{C}=$ Rational method runoff coefficient

A $=$ Drainage area $\left(\mathrm{m}^{2}\right)$

I $=$ Rainfall intensity $(\mathrm{m} / \mathrm{s})$

\subsection{Hydraulic analysis method}

Channel capacity is the maximum discharge that can be passed by a section along the river. This capacity determines whether a river can accommodate a flow discharge without overflowing or not. The formula to calculate channel capacity is the Manning equation:

$$
Q=\frac{1}{n} R^{\frac{2}{3}} S^{1 / 2} A
$$

$$
\begin{array}{ll}
\mathrm{Q} & =\text { Discharge }\left(\mathrm{m}^{3} / \mathrm{s}\right) \\
\mathrm{n} & =\text { Manning's coefficient } \\
\mathrm{R} & =\text { The hydraulic radius } A / P_{\mathrm{w}}(\mathrm{m}) \\
\mathrm{A} & =\text { Cross-sectional area of the flow } \\
\mathrm{S} & =\text { The slope of the water surface }
\end{array}
$$

\subsection{Erosion rate analysis method}

In this study, the erosion rate in Cipamokolan River will be calculated. The method used to calculate the erosion rate is the USLE method.

USLE allows planners to estimate the average erosion rate of a particular soil in a steep slope with a certain rainfall pattern for each type of cropping and management action (soil conservation measures) that may be carried out or being used [6].

Mathematically the equation is denoted as:

$$
A(\text { tons } / \text { ha/year })=R * K * L * S * C * P
$$

$\mathrm{A}=$ Annual soil loss

$\mathrm{R}=$ Rainfall and runoff erosivity index

$\mathrm{K}=$ Soil-erodibility factor

$\mathrm{L}=$ Length of slope factor

$\mathrm{S}=$ Degree of slope factor

$\mathrm{C}=$ Cropping-management factor

$\mathrm{P}=$ Conservation practice factor
1. Soil-erodibility factor $(\mathrm{K})$

The soil erodibility factor $(\mathrm{K})$, represents both susceptibility of soil to erosion and the amount and rate of runoff, as measured under standard plot conditions. The parameters used to obtain soil erodibility coefficient are the percentage of sand, the level of organic matter in the soil, soil structure, and soil permeability. The following is the Wischmeier dan Smith (1978) equation and the parameter table used to calculate soil erosivity [6].

$$
\begin{aligned}
& K=\left(2.723 * M^{1.34 * 10^{-4}}(12-a)+3.25(b-2)\right. \\
& +2.5(c-3)) / 100
\end{aligned}
$$

$\mathrm{K}=$ Soil erodibility factor

$\mathrm{M}=[$ (the percentage of very fine sand and dust $) *(100-$ the percentage clay)] (Table 1)

a $=$ the level of organic matter in the soil

$\mathrm{b}=$ the level of soil structure (Table 2)

c $\quad=$ the level of soil permeability (Table 3)

Table 2. Soil texture [7]

\begin{tabular}{|c|c|c|}
\hline No. & Soil Texture (USDA) & M \\
\hline 1 & Heavy clay & 210 \\
\hline 2 & Medium clay & 750 \\
\hline 3 & Sandy clay & 1213 \\
\hline 4 & Sandy clay loam & 1685 \\
\hline 5 & Dusty clay & 2160 \\
\hline 6 & Clayey loam & 2830 \\
\hline 7 & Sand & 3035 \\
\hline 8 & Sandy loam & 3245 \\
\hline 9 & Dusty clay loam & 3770 \\
\hline 10 & Clay & 4390 \\
\hline 11 & Dusty loam & 6330 \\
\hline 12 & Dust & 8245 \\
\hline
\end{tabular}

Table 3. Level of soil structure [8]

\begin{tabular}{|r|l|c|}
\hline No. & Class of Soil Structure & Level \\
\hline 1 & Granular is very smooth & 1 \\
\hline 2 & Fine granular & 2 \\
\hline 3 & Medium to rough granular & 3 \\
\hline 4 & Lumpy, slab, solid & 4 \\
\hline
\end{tabular}

Table 4. Level of soil permeability [8]

\begin{tabular}{|r|l|c|}
\hline No & \multicolumn{1}{|c|}{ Soil Permeability } & Level \\
\hline 1 & Very slow $(<0.5 \mathrm{~cm} /$ hour $)$ & 6 \\
\hline 2 & Slow $(0.5-2 \mathrm{~cm} /$ hour $)$ & 5 \\
\hline 3 & Slow to moderate $(2-6.3 \mathrm{~cm} /$ hour $)$ & 4 \\
\hline 4 & Medium $(6.3-12.7 \mathrm{~cm} /$ hour $)$ & 3 \\
\hline 5 & Medium to fast $(12.7-25.4 \mathrm{~cm} /$ hour $)$ & 2 \\
\hline 6 & Fast $(>25.4 \mathrm{~cm} /$ hour $)$ & 1 \\
\hline
\end{tabular}

2. Rainfall and runoff erosivity index (R) 
In this study, to calculate the value of erosivity used Roose (1975) method, with the equation as follows:

$$
R=0.5 R_{a}
$$

$\mathrm{R}=$ rainfall erosivity (ft.ton/acre)

$\mathrm{R}_{\mathrm{a}}=$ yearly rainfall (mm) [6]

\section{Slope Factor (LS)}

The slope factor is obtained from the multiplication of slope length factors and slope slope factors. In this study, to calculate the value of slope factor used Wischmeier\&Smith (1965) Equation as follows:

$$
L S=\left(\frac{x}{22.13}\right)^{n}\left(0.065+0.045 s+0.0065 s^{2}\right)
$$

$$
\begin{array}{ll}
\mathrm{x} & =\text { length of slope }(\mathrm{m}) \\
\mathrm{s} & =\text { degree of slope factor }(\%) \\
\mathrm{n} & =0.3 \text { for slope }<=3 \% \\
\mathrm{n} & =0.4 \text { for slope }=4 \% \\
\mathrm{n} & =0.5 \text { for slope }>=5 \%[6]
\end{array}
$$

\begin{tabular}{|c|c|c|c|c|c|c|c|c|}
\hline \begin{tabular}{|l} 
Type and Height \\
\end{tabular} & Percentage & & & & intage & nd Cove & & \\
\hline Canopi & Canopi Cover (\%) & Type & 0 & 20 & 40 & 60 & 80 & 95-100 \\
\hline & & G(grass) & 0.45 & 0.2 & 0.1 & 0.042 & 0.013 & 0.003 \\
\hline Canopi & & W(weeds) & 0.45 & 0.24 & 0.15 & 0.09 & 0.043 & 0.011 \\
\hline Canopi $\pm 0,5 \mathrm{~m}$ & 25 & G & 0.36 & 0.17 & 0.09 & 0.038 & 0.012 & 0.003 \\
\hline $\begin{array}{l}\text { (grass) } \\
\end{array}$ & & W & 0.36 & 0.2 & 0.13 & 0.082 & 0.041 & 0.011 \\
\hline & 50 & G & 0.26 & 0.13 & 0.07 & 0.035 & 0.012 & 0.003 \\
\hline & & w & 0.26 & 0.16 & 0.11 & 0.075 & 0.039 & 0.011 \\
\hline & 75 & G & 0.17 & 0.1 & 0.06 & 0.031 & 0.011 & 0.003 \\
\hline & & W & 0.17 & 0.12 & 0.09 & 0.068 & 0.038 & 0.011 \\
\hline \begin{tabular}{|l|} 
Canopi $\pm 2,0 \mathrm{~m}$ \\
\end{tabular} & 25 & G & 0.4 & 0.18 & 0.09 & 0.04 & 0.013 & 0.003 \\
\hline (shrubs) & & W & 0.4 & 0.22 & 0.14 & 0.085 & 0.042 & 0.011 \\
\hline & 50 & G & 0.34 & 0.16 & 0.085 & 0.038 & 0.012 & 0.003 \\
\hline & & W & 0.34 & 0.19 & 0.13 & 0.081 & 0.041 & 0.011 \\
\hline & 75 & G & 0.28 & 0.14 & 0.08 & 0.036 & 0.012 & 0.003 \\
\hline & & W & 0.28 & 0.17 & 0.12 & 0.077 & 0.04 & 0.011 \\
\hline \begin{tabular}{|l|} 
Canopi $\pm 4,0 \mathrm{~m}$ \\
\end{tabular} & 25 & G & 0.42 & 0.19 & 0.1 & 0.041 & 0.013 & 0.003 \\
\hline (trees) & & W & 0.42 & 0.23 & 0.14 & 0.087 & 0.042 & 0.011 \\
\hline & 50 & G & 0.39 & 0.18 & 0.09 & 0.04 & 0.013 & 0.003 \\
\hline & & W & 0.39 & 0.21 & 0.14 & 0.085 & 0.042 & 0.011 \\
\hline & 75 & G & 0.36 & 0.17 & 0.09 & 0.039 & 0.012 & 0.003 \\
\hline & & W & 0.36 & 0.2 & 0.13 & 0.083 & 0.041 & 0.011 \\
\hline
\end{tabular}

\section{Cropping-management factor (C)}

The vegetation coefficient factor (C) can be predicted based on the dominant vegetation. The table below is the value of $\mathrm{C}$ in various conditions of the type of vegetation [6].

Table 5. Percentage of C

\section{Conservation practice factor $(\mathrm{P})$}

By definition, the factor $\mathrm{P}$ in the USLE is the ratio of soil loss with a specific practice to the corresponding loss support with up and down slope culture. Improved tillage practices, sod-based rotations, fertility treatments and greater quantities of crop residues left on the field contribute materially to erosion control and often provide the major control in a farmer's field [9]. Assuming no practice support in the study area, it was not used in calculations $(\mathrm{P}$ factor $=1)[6]$.

\subsection{Erosion hazard classification}

Erosion hazard evaluation or also called erosion hazard level is determined based on the ratio between the amount of actual soil erosion and tolerable soil erosion. to determine erosion events at a dangerous level or not, it can be seen from the level of erosion hazard [8].

The United States Department of Agriculture (USDA) has determined erosion hazard levels based on erosion rates which can be seen in the following table.

Table 6. Erosion hazard class [10]

\begin{tabular}{|c|c|l|l|}
\hline No. & $\begin{array}{c}\text { Erosion } \\
\text { Hazard } \\
\text { Class }\end{array}$ & $\begin{array}{c}\text { Erosion Rate } \\
\text { (ton/ha/year) }\end{array}$ & \\
\hline 1 & I & $<15$ & Very low \\
\hline 2 & II & $15-60$ & Low \\
\hline 3 & III & $60-180$ & Medium \\
\hline 4 & IV & $180-480$ & High \\
\hline 5 & V & $>480$ & Very high \\
\hline
\end{tabular}

\section{Result and discussion}

\subsection{Hydrological analysis}

In this study, flood discharge in Cipamokolan River on March 20, 2018 will be calculated. The data used for calculating flood discharge are as follows:

1. Rainfall intensity is $45 \mathrm{~mm} / \mathrm{hour}$.

BMKG stated that intensity rainfall on 20 March was $45 \mathrm{~mm} /$ hour and occurred for 2 hours. Based on $\mathrm{BMKG}$ data, extreme rain has rainfall intensity more than $20 \mathrm{~mm} /$ hour. So, its rainfall event is classified as extreme rain.

2. Runoff coefficient is 0.85

Based on image data obtained from Google Earth, it can be seen that the North Bandung Region and the Jatihandap Area are dominated by settlements and open land. So it is assumed that the land cover coefficient is 0.85 .

3. Watershed area of Cipamokolan River is $6.5 \mathrm{~km}^{2}$ Based on spatial analysis, it was found that the watershed area was $6.5 \mathrm{~km}^{2}$. The width of the watershed can be seen in the following figure:

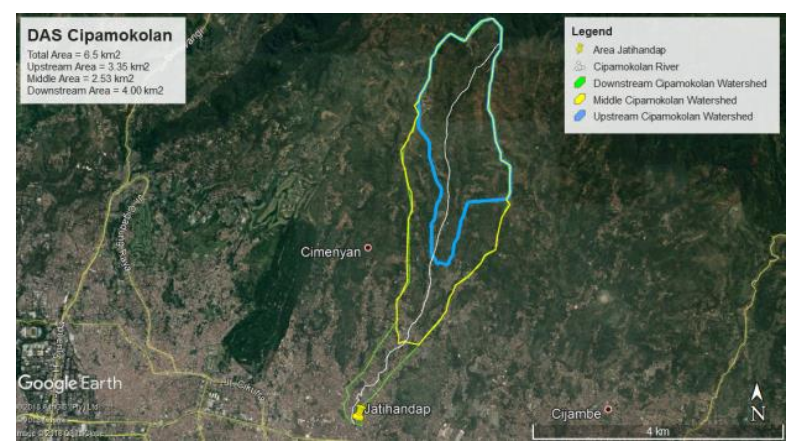

Fig. 2. Catchment Area of Cipamokolan River

Based on the data that has been obtained, it can be calculated the flood discharge that occurred at that time.

$$
Q=0.85 * \frac{45 * 10^{-3}}{3600} \frac{\mathrm{m}}{\mathrm{s}} * 6.5 * 10^{6} \mathrm{~m}^{2}
$$




$$
Q=69 \mathrm{~m}^{3} / \mathrm{s}
$$

At that time the water flow also contained high sediment concentrations. The author assumes at that time, the ratio between the discharge of water and sediment carried by the flow is $1: 2$, so that when calculated between water discharge and sediment discharge in the flow, the flow rate at that time is three times from the discharge calculation by the rational method.

$$
\begin{gathered}
\text { Qtotal }=3 * \text { Qwater } \\
\text { Qtotal }=3 * 69=207 \mathrm{~m}^{3} / \mathrm{s}
\end{gathered}
$$

So, in the event of a flood, it can be predicted that the flow rate of the river is equal to $207 \mathrm{~m}^{3} / \mathrm{s}$. The discharge tends to be high when compared to rivers which based on observations only have an average width of $4.15 \mathrm{~m}$.

\subsection{Hydraulic analysis}

With the width of the river $4.15 \mathrm{~m}$, the discharge in the river crossing can be calculated using the manning equation. Due to limited data, the author assumes the river channel is the economical trapezoidal channel with a slope of 0.01 and roughness coefficient of manning the river 0.035 . based on these assumptions, it can be predicted that the river can only accommodate flows of:

$$
\begin{gathered}
Q=\frac{1}{n} *\left(\frac{\sqrt{3}}{4} B\right)^{\frac{2}{3}} * S^{\frac{1}{2}} *\left(\frac{3}{4} \sqrt{3}\right) B^{2} \\
Q=\frac{1}{0.035} \times\left(\frac{\sqrt{3}}{4} 4.15\right)^{2 / 3} \times 0.01^{1 / 2} \times\left(\frac{3}{4} \sqrt{3}\right) 4.15^{2}
\end{gathered}
$$

$$
Q=94.5 \mathrm{m3} / \mathrm{s}
$$

If the discharge from the calculation above compared to the flow rate, the discharge that occurs when flash flood is 2.2 times greater than the river crossing discharge. That is why the Cipamokolan River overflowed due to insufficient river storage capacity, and also the river has a relatively small width, which causes debris waste to be hampered in several points that cause the water structure around the river to also be damaged.

\subsection{Erosion rate analysis}

Because of extreme rainfall and land use changes, the flash flood occurred due to the high rate of erosion in the Cipamokolan Watershed especially in the upstream area. So that when rain occurs, erosion in the area is higher and causes high flow of debris accompanied by debris waste. Analysis of erosion rates were calculated using USLE method by assuming some parameters. The following parameters are used in USLE calculations to predict the rate of erosion in the Cipamokolan watershed every year.

1. Soil-erodibility factor

In the area of North Bandung, the dominating soil type is andosol with sorrel color, contains a lot of the organic component of soil, and there is a mountain sand content.
Soil texture in the area has a composition of $34.8 \%$ sand fraction, $49.73 \%$ dust and $15.45 \%$ clay, based on this percentage it can be concluded that the soil texture is clay. [11].

With the structure and soil content, soil erosivity can be calculated by referring to table 1 , table 2 , and table 3 . Grain size assessment (M) is 4,390, the level of the soil structure is 2 , and the value of soil permeability is 2 . The following is the calculation of soil erosivity.

$$
\begin{gathered}
K=\left(2.723^{*} 1685^{1.14 * 10^{-4}}(12-2)+3.25(3-2)+2.5(3-3)\right) / 100 \\
K=0.16
\end{gathered}
$$

\begin{tabular}{|c|c|}
\hline Month & Ri (mm) \\
\hline August & 45.7 \\
\hline September & 90.8 \\
\hline October & 345.3 \\
\hline November & 431.1 \\
\hline December & 129.9 \\
\hline January & 190.8 \\
\hline February & 239.3 \\
\hline March & 292 \\
\hline April & 297.5 \\
\hline May & 123.9 \\
\hline June & 33.4 \\
\hline July & 0.3 \\
\hline Total (mm) & 2220 \\
\hline
\end{tabular}

2. Rainfall and runoff erosivity index

To calculate the value of rainfall erosivity using the Roose method. The data used is rain data of Bandung Geophysical Station in August 2017- July 2018. The following is the result of calculating the value of rainfall erosivity.

Table 7. Rainfall erosivity

\section{Slope factor}

Slope factor calculation using Wischmeier\&Smith (1965) equation. In this study, the calculation of slope factor divide in 3 areas, that are Upstream Cipamokolan watershed, Middle Cipamokolan Watershed, and Downstream Cipamokolan Watershed.

a. Upstream Cipamokolan Watershed

Known length of slope is $3470 \mathrm{~m}$, degree of slope is $13 \%$, and $n$ value is 0.5 . The following is the result of calculating the value of slope factor.

$$
\begin{gathered}
L S=\left(\frac{3470}{22.13}\right)^{0.4}\left(0.065+0.045 \times 0.13+0.0065 \times 0.13^{2}\right) \\
L S=0.92
\end{gathered}
$$

b. Middle Cipamokolan Watershed Known length of slope is $1530 \mathrm{~m}$, degree of slope is $8 \%$, and $\mathrm{n}$ value is 0.5 . The following is the result of calculating the value of slope factor. 


$$
\begin{gathered}
L S=\left(\frac{3470}{22.13}\right)^{0.4}\left(0.065+0.045 \times 0.08+0.0065 \times 0.08^{2}\right) \\
L S=0.57
\end{gathered}
$$

c. Downstream Cipamokolan Watershed

Known length of slope is $1900 \mathrm{~m}$, degree of slope is $3 \%$, and $n$ value is 0.3 . The following is the result of calculating the value of slope factor.

$$
\begin{gathered}
L S=\left(\frac{3470}{22.13}\right)^{0.4}\left(0.065+0.045 \times 0.03+0.0065 \times 0.03^{2}\right) \\
L S=0.25
\end{gathered}
$$

4. Cropping-management factor $(\mathrm{C})$

It is known that the watershed of cipamokolan dominant vegetation is shrub with a percentage of land cover of $20 \%$. Based on that and table 4 , the value of $\mathrm{C}$ is 0.22 .

5. Conservation practice factor $(\mathrm{P})$

For value of $\mathrm{P}$, assuming no practice support in the study area, it was not used in calculations, so P factor is 1.

6. Erosion Rate (A)

Based on the results of previous calculations, obtained:

Table 8. Parameter of erosion rate

\begin{tabular}{|c|c|c|}
\hline Parameter & Nilai & Satuan \\
\hline K & 0.417854 & \\
\hline R & 36803.88 & ton/ha \\
\hline LS & 1.244034 & \\
\hline C & 0.22 & \\
\hline P & 1 & \\
\hline
\end{tabular}

So the erosion rate in Cipamokolan Watershed divide in 3 value per area because the value of LS divide in 3 areas.

$$
A=\text { K.R.LS.C.P }
$$

a. Upstream Area

$$
\begin{gathered}
A=0.1618 \times 19203 \times 0.92 \times 0.22 \times 1 \\
A=628.86 \text { ton } / \text { ha } / \text { year } \\
\text { with } \gamma=2.535 \mathrm{ton} / \mathrm{m}^{3} \\
\mathrm{~A}=\frac{628.86 \frac{\mathrm{ton}}{\mathrm{ha}} / \text { year }}{2.535 \mathrm{ton} / \mathrm{m} 3}=24.81 \mathrm{~mm} / \text { year }=2.4 \mathrm{~cm} / \text { year }
\end{gathered}
$$

b. Middle Area

$$
\begin{gathered}
A=0.1618 \times 19203 \times 0.57 \times 0.22 \times 1 \\
A=391.39 \text { ton } / \text { ha } / \text { year } \\
\text { with } \gamma=2.535 \mathrm{ton} / \mathrm{m}^{3} \\
\mathrm{~A}=\frac{391.39 \frac{\text { ton }}{\mathrm{ha}} / \text { year }}{2.535 \text { ton } / \mathrm{m} 3}=15.44 \mathrm{~mm} / \text { year }=1.55 \mathrm{~cm} / \text { year }
\end{gathered}
$$

c. Downstream Area

$$
\begin{gathered}
A=0.1618 \times 19203 \times 0.25 \times 0.22 \times 1 \\
A=172.05 \text { ton } / \text { ha/year }
\end{gathered}
$$$$
\text { with } \gamma=2.535 \text { ton } / \mathrm{m}^{3}
$$

$$
\mathrm{A}=\frac{172.05 \frac{\text { ton }}{\mathrm{ha}} / \text { year }}{2.535 \mathrm{ton} / \mathrm{m} 3}=6.79 \mathrm{~mm} / \text { year }=0.679 \mathrm{~cm} / \text { year }
$$

Based on the calculation, the value of erosion rate in each area is different. The upstream area shows the higher value of erosion rate rather than the erosion rate in the middle and downstream area.

The erosion rate is then classified with erosion hazard classification by USDA that can see in table 5 . Table 8 shows the erosion rate classification from the calculation.

Table 9. Result of erosion rate classification

\begin{tabular}{|r|l|c|l|}
\hline No. & \multicolumn{1}{|c|}{ Area } & $\begin{array}{c}\text { Value of } \\
\text { Erosion Rate } \\
\text { (ton/ha/year) }\end{array}$ & $\begin{array}{c}\text { Category } \\
\text { Hazard } \\
\text { Erosion }\end{array}$ \\
\hline 1 & Upstream & 628.86 & Very High \\
\hline 2 & Middle & 391.39 & High \\
\hline 3 & Downstream & 172.06 & Medium \\
\hline
\end{tabular}

Based on these results, the upstream erosion hazard is very high. If associated with flash flood events, with high erosion potential in the upstream area and high rainfall occurred on 20 March 2018 around the KBU area causing high erosion in the area, the results of erosion is debris waste (soil, rocks, tree trunks, garbage) then carried by the flow and accumulated at one point. Trash that continues to accumulate will form a natural weir that blocks the flow of water from the upstream. With a large water rate and high discharge, the natural weir cannot resist the pressure due to current and discharge, so that the natural weir was collapsed. the collapse of the weir causes the flow of water going downstream with higher velocity so that it damaged the embankments around and causes flash floods.

\section{Conclusion and recommendations}

On March 20, 2018 there was a flash flood in the Jatihandap area. Flash flood is caused by several factors they are high rainfall intensity of $45 \mathrm{~mm}$ /hour, lack of water catchment area, soil erosion, and others. The discharge that occurred on that day reached $207 \mathrm{~m}^{3} / \mathrm{s}$. The flow does not only carry water but contains high concentrations of sediment and debris waste. This causes damage to the embankment in the Jatihandap area so that flash floods occured there.

Based on calculations, it is known that on Cipamokolan watershed, the erosion rate is very high. If it continues to be left, it will become a dangerous threat, it does not rule out the possibility of flash floods will occur again in the area if no land repairs and maintenance are carried out. 
In order for the same thing not to happen again, the authors recommend several things, that are:

1. It is necessary to make efforts to improve the river structure in the form of embankment repairs, strengthening of cliff walls, strengthening river channels, and river slopes.

2. Reforestation and land improvement in the northern Bandung region also need to be done, considering that the large number of settlements and plantations in the area is one of the causes of high erosion rates.

3. It is also necessary to apply the plan of behavior theory to everyday life, especially to the community around Cipamokolan watershed. This is done to make people aware of the importance of the role of the community in protecting the surrounding environment, including Cipamokolan Watershed, so that similar things do not happen again.

The author also suggests for better research in the future, it is better to collect data such as rainfall data, observation debit, land cover, land data, and others from related institutions, so that calculations can be more accurate.

We are thankful to each person who has involved in this project. We would also like to thank our paper reviewers for the insights to make this paper better.

\section{References}

1. West Java Province Government. Peraturan Daerah Nomor 2 Tahun 2016 tentang Pedoman Pengendalian Kawasan Bandung Utara sebagai Kawasan Strategis Provinsi Jawa Barat. Bandung. (2016)

2. T.M. Carpenter, S.V. Taylor, K.P. Georgakakos, J. Wang, E. Shamir, J.A. Sperfslage, Surveying flash flood response in mountain streams. Eos Trans. AGU 88 (6). doi:10.1029/2007EO060001 (2007)

3. A. Nurrohman, The Condition of Citarum Watershed Land Cover In Bandung Utara Area $(K B U)$. Article in http://dlh.jabarprov.go.id. (2018)

4. A. Deviana et al. Kajian Pemodelan Spasial Banjir Untuk Mendukung Kebijakan Sempadan Sungai dan Tata Ruang Wilayah (Studi Kasus Wilayah Pengembangan Baleendah). Bandung.

5. Purnomo, Wisang Adhitya Yogo. Efektifitas Pengendalian Banjir DAS Citarum Bagian Hulu Melalui Pengendalian Pemanfaatan Lahan dan Normalisasi Alur Sungai. Depok. (2012)

6. R.H. Anasiru and B.B Tilongkabila. Perhitungan Laju Erosi Metode Usle Untuk Pengukuran Nilai Ekonomi Ekologi Di Sub Das Langge, Gorontalo. (2015)

7. S. Hardjowigeno, Ilmu Tanah Edisi Baru : Cetakan ketujuh. Penerbit Akademika Pressindo. Jakarta. (2010)

8. Arsyad. Konservasi Tanah dan Air. Institut Pertanian Bogor (IPB). Bogor. (2010)

9. TOMBUŞ, Fazlı Engin and friends. Assessment Of Soil Erosion Based On The Method USLE; Çorum Province Example. (2012)
10. Suripin. Pelestarian Sumberdaya Tanah dan Air. Andi Offset. Yogyakara (2001)

11. R. Widiriani, "Model Ecofarming untuk Mewujudkan Sistem Usahatani Berkelanjutan di Lahan Dataran Tinggi Yang Telah Dimanfaatkan oleh Masyarakat: Kasus di Kecamatan Lembang, Kabupaten Bandung Barat dan Kecamatan Dongko, Kabupaten Trenggalek". Disertation. Sekolah Pascasarjana Institut Pertanian Bogor. (2009)

12. Thompson, David B. The Rational Method. (2006) 